\title{
DESCATEGORIZAR E RECATEGORIZAR A POIÉSIS A PARTIR DO DIGITAL
}

\author{
Entrevista com Álvaro Andrade Garcia
}

Patrícia Chanely Silva Ricarte* Rogério Barbosa da Silva ${ }^{* *}$

Escritor e diretor de audiovisual e multimídia, Álvaro Andrade Garcia tem dez livros de poesia e três de prosa publicados, e dedica-se, desde a década de 1980, a produzir poesia em vídeo, com a mediação do computador e, ultimamente, em plataformas multimídias e digitais. Seu poema O Buda da Palavra participou da instalação Bunker Poético, de Harald Szeemann, na 49를 Bienal de Veneza, em 2001. Tem poemas publicados na revista 34 Letras e no Suplemento Literário de Minas Gerais. Participou da antologia Taquicardias, da Temporada de Poesia, da Poesia Orbital e do jornal Dezfaces. Exibiu videopoemas em Belo Horizonte, Rio de Janeiro e São Paulo na década de 1980. Desde a década de 1990, tem dirigido vários projetos multimídia, sites e portais na internet. Desenvolveu uma instalação audiovisual sobre biomas brasileiros, voltada para o Espaço Israel Pinheiro, em Brasília, que foi exibida durante quatro anos no Espaço do Conhecimento UFMG, em Belo Horizonte. Trabalha, atualmente, no projeto do curta-metragem interativo O Ocidental, na continuação da trilogia "AOM" iniciada com o livro Grão e o software Managana - e na finalização do seu primeiro romance, $O$ Coração de Outono. Sua produção criativa e crítica pode ser acessada através do sítio Ciclope.art, no endereço http://www.ciclope.com.br/ .

\footnotetext{
*Universidade Federal de Santa Catarina, Florianópolis, Brasil. Imeio: patricarte@gmail.com

Centro de Educação Tecnológica de Minas Gerais, Belo Horizonte, Brasil. Imeio: rogeriobsilvacefet@gmail.com
} 
Ao participar do II Simpósio Internacional e VI Simpósio Nacional de Literatura e Informática, realizado pelo Núcleo de Pesquisas em Informática, Literatura e Linguística - NUPILL, da Universidade Federal de Santa Catarina, em Florianópolis, entre os dias 02 e 13 de dezembro de 2013, Álvaro Andrade Garcia nos concedeu esta que é a primeira da série de entrevistas "Conversas com Criadores Digitais Brasileiros" da revista Texto Digital.

Rogério Barbosa da Silva: Inicialmente, gostaríamos que você falasse um pouco sobre como foi o começo de seu percurso na poesia, como se iniciou o seu trabalho com a poesia impressa e o diálogo que você empreende entre a poesia e os meios digitais.

Álvaro Andrade Garcia: Bom, eu comecei a ser "picado" pela poesia mais ou menos no final do meu curso universitário. Eu estava me formando em medicina e simultaneamente começando a escrever coisas, tanto na área de prosa quanto na de poesia. Na verdade, eu escrevo nessas duas vertentes. Assim que eu me formei, resolvi parar um pouco o percurso profissional que estava seguindo e me testar, me experimentar como escritor. Nesse momento, que é o início da década de 1980, estavam surgindo o processador de textos e o computador pessoal. É exatamente nesse momento, então, que compro meu primeiro PCXT, o qual, aliás, foi o primeiro de todos os PC's. Era um modelo portátil mais ou menos deste tamanho [demonstra com as mãos dimensões em torno de 17 polegadas], chamado Lunch Box. Era como se fosse uma lancheira com um teclado, um monitorzinho de fósforo verde e um disquete para o programa (o processador de textos) e outro disquete para os seus dados. Então, meu primeiro contato com a informática veio por essa busca por um processador de textos, numa época em que nem isso existia. Nós estávamos no Word para DOS 1.0, no Word para DOS 2. O programa que as pessoas mais usavam se chamava Word Star, que depois sumiu na poeira do tempo. Então, começo a trabalhar com o computador e descubro uma coisa que hoje é óbvia: isso de o processador de textos transformar a palavra em uma geleia moldável, ou seja, essa possibilidade de se recorrer à edição infinitamente, de mexer, mover... Muita gente se esquece como 
era o processo braçal de trabalho do escritor, de emendas, de bater por cima, de redatilografar coisas ou transcrever...

Rogério: O manuscrito...

Álvaro: Isso, o manuscrito. Ainda nesse processo, com esse mesmo computador, tive acesso a um programa que seria, vamos dizer, o avô do Power Point: um programa da IBM que se chamava Presentation Manager, feito para apresentações. Ele encadeava telas, tinha um efeito de passagem entre uma tela e outra, alguma coisa de animação, um grafismo ainda rudimentar. Estou falando de um computador que tinha ainda 320 por 240 pixels, em que se viam no máximo quatro cores simultâneas. Ao mesmo tempo, eu me articulei com outros criadores em algo que nós chamamos, à época, de "Oficina Literária Informatizada". Nesse grupo, estavam o Delfim Afonso, o Mário Flecha e o Roberto Barros. O Roberto era jornalista e escritor. O Delfim era professor de comunicação e semiótica. E o Mário era analista de sistemas. Ele trabalhava com mainframes, com computadores mais pesados, já tinha noção de programação. Eu era completamente neófito. E a gente, então, teve uma ideia: por que não pegamos esse programa que gerencia apresentações e fazemos poesia com ele? Aí começa, então, a minha carreira na videopoesia.

Rogério: Tinha alguma dimensão visual da poesia que lhe orientava nesse momento?

Álvaro: Não. Nós começamos a trabalhar em cima de textos, ou seja, do impresso. Hoje, tenho textos que já fui fazendo direto no digital e depois imprimi, ou vice-versa. Mas, naquele momento, pegamos, na verdade, textos do impresso com alguma característica que chamasse para a visualidade. O computador não tocava som nessa época. Eu estou falando de 1984, por aí. O kit multimídia vai chegar no início da década de 1990. Por volta de 1992, é que vêm o CD-player e a placa de som, com os quais, de fato, o computador ganha uma dimensão audiovisual. E, nesse momento, também, as placas de vídeo já tinham mais cores, mais definição. Não se estava mais numa interface de texto. Já existiam o 
Windows, o Macintosh. Mas, nesse início, as coisas ainda eram áridas nesse sentido. Portanto, a nossa apropriação foi bastante lúdica: "Por que não? Vamos experimentar!" Começamos a trabalhar com isso. Deu certo. E, em cima dessa experiência, começamos a exibir esses videopoemas em algumas cidades. Tratase de coisas que são banais, mas que, na época, não o eram. Por exemplo: para ligar um telão com projetor no computador, tivemos que desenvolver uma interface, literalmente. Havia uma empresa chamada Versão Brasileira que nos patrocinava. A partir de um dos sócios dessa empresa, cujo irmão trabalhava numa indústria de computadores, desenvolvemos essa interface. Havia a Lei da Informática no Brasil nessa época. Esse é o início do meu trabalho digital. Fizemos essas pequenas experiências com videopoesia, com o uso intenso do processador de textos na parte de criação. E também fizemos muita experimentação com algo que ainda era absolutamente inédito: a editoração eletrônica [Risos]. Começamos a produzir os próprios livros, a diagramar etc.

Rogério: Nesse sentido, você se insere em um grupo de pioneiros da poesia e da criação digitais. Vocês tinham contato com outros grupos no Brasil?

Álvaro: Acompanhamos, de certa forma, o que estava ocorrendo nessa área no país. Fizemos essa turnê rodando pelo Brasil para exibir esses poemas em 1987. Conversando com o Wilton Azevedo, fiquei sabendo que também foi nessa época que ele, Philadelpho Menezes e outros grupos estavam trabalhando. É nessa época também que temos o Arnaldo Antunes começando a trabalhar com isso. Tem também os irmãos Campos e outras pessoas ligadas à Poesia Concreta. Esse primeiro surto que acontece no Brasil ocorre mais ou menos nessa época.

Rogério: É algo que tem coincidência com o aparecimento dessas tecnologias.

Álvaro: Eu penso que foi justamente pelo barateamento da tecnologia, com o surgimento do computador pessoal. Há algumas experiências antes disso de pessoas que trabalharam com mainframes, com cartão perfurado. Mas a coisa começa a se alastrar, a ganhar a cara do que é hoje, a partir desse momento da popularização do PC na década de 1980. E ela explode na década de 1990, dentre outros fatores, por causa disso. O PC precisou aprender com as artes a se 
tornar mais amigável. Ele era uma coisa com a qual era extremamente difícil se relacionar.

Rogério: Há uma produção sua chamada Pepsi Machine, na qual você lida com a experiência do computador na videopoesia. Trata-se de um trabalho interlínguas, por conta do inglês usado na máquina de refrigerantes. Como você hoje vê essa criação?

Álvaro: Em uma linha evolutiva, houve uma primeira série dessa produção, que foi o Quarteto de Sopros, o qual coincidiu com aquela articulação de autores. Depois, acabamos nos dispersando. Aquele grupo se desfez. E eu fiquei pobre [Risos]. Pedi demissão de onde eu trabalhava. Eu não tinha dinheiro. Então, tive uma ideia. Eu percebia esse potencial da videopoesia. Procurei essa empresa que nos patrocinava e propus o seguinte a eles: "Vocês não querem um sócio para pensar no setor de computação gráfica?" Em Minas Gerais, havia, até então, uma única empresa que fazia vinhetas e títulos, ou seja, computação gráfica para utilização em audiovisual: o Sistema Salesiano de Vídeo.

Patrícia Chanely Silva Ricarte: Isso foi em que ano?

Álvaro: Isso foi no final dos anos 80 e início dos anos 90. Enfim, eles toparam na hora. Eu entrei para a empresa. E foi essa empresa que montamos que acabou resultando no Ateliê Ciclope, criado em 92. Em 98, os outros sócios saem e a Ciclope fica só comigo. Esse início, nos anos 90, é muito rico para essa experiência toda de que estamos falando, porque, nessa época, já existem computadores com placas gráficas. Já surgia o Animator, já surgiam os primeiros programas em 3D, o AutoCAD... Eu passo, então, a dividir o meu tempo, fazendo, simultaneamente, trabalho de literatura e uma produção comercial e institucional com essas ferramentas. Nesse contexto, se insere o Pepsi Machine. Eu começo também a produzir livros artesanais, mas feitos em computador: A Faculdade dos Sensos e uma novela que se chama Ana, cujas capas foram feitas pelo Eduardo de Jesus, que trabalhava comigo na época. Nós trabalhávamos no computador e imprimíamos em tiragens menores. E, então, surge a proposta de fazer o Pepsi Machine, que já faz esse salto todo de que estamos falando. Ele já tem áudio. Foi 
feito em um programa de modelagem tridimensional. Ou seja, adquirimos com ele uma série de recursos. Há um texto meu em que tento falar dessa passagem: "Da videopoesia à imaginação digital". Nesse primeiro momento, a ideia de poesia para a tela ainda era a grande atração, mais até do que a questão da interatividade, que é posterior. A pesquisa era muito mais em torno da introdução do movimento, da leitura não-linear, do tamanho das palavras e da posição relativa delas, ou seja, da composição de uma tela móvel e em torno do que isso causava de transformação no texto e na poesia. De certa forma, isso é o que já se estava pensando no papel, com a Poesia Concreta e com diversas outras experiências pré-computacionais que também discutiam o fim do verso tradicional e uma série de questões que começamos a pensar a partir da tela.

Rogério: Você tem uma produção crítica e ensaística - a qual, inclusive, encontra-se hospedada em seu site - que mostra certa necessidade sua no sentido de falar sobre o seu campo de criação. Isso se deve, de alguma maneira, a uma ausência de estudos acadêmicos, críticos ou teóricos sobre esse tipo de obra?

Álvaro: De fato, como se trata de um momento extremamente pioneiro, em certo sentido, havia muito pouca literatura ou muito pouca experiência prévia em relação ao que estávamos fazendo. E tínhamos também de adquirir experiência usando outros materiais, outras coisas, no sentido de buscar metáforas ou ideias para tratar a questão do movimento, da projeção do texto, ou seja, essas transformações de que estamos falando. Mas cada um faz isso de um jeito. Tenho um rascunho enorme de um livro que comecei a desenvolver com a professora Maria Aparecida Moura, da UFMG, que se chamava Multimídia. Fazer e Pensar. Mas, nesse período, que é dos anos 90 em diante, eu já estou com a produtora, a qual se torna, depois, uma das três primeiras produtoras de multimídia do Brasil. A gente já entra como a primeira empresa de Minas a fazer um CD-Rom.

Patrícia: Em Pepsi Machine, parece haver uma visão crítica em relação ao capitalismo, ao consumo. Por outro lado, você exerce um papel de produtor, de empresário. De que forma, então, você acredita que a sua arte atua no sentido de fazer a crítica do contemporâneo e, ao mesmo tempo, trazer a sua visão acerca 
de seu próprio papel nessas duas frentes, que poderiam ser tomadas como antagônicas, mas que você parece ter conseguido casar, até para a sobrevivência da arte?

Álvaro: Como eu disse há pouco, foi uma questão de sobrevivência minha, mesmo. Para fazer arte, eu tenho que viver. Então, nesse primeiro momento, acontece isso. $E$, na videoarte, era mais ou menos assim também. O pessoal fazia videoarte e possuía a produtora de vídeo para fazer. Tínhamos esse modelo. Sempre gostei dessa história do multimídia fazer pensar. Nessa década de 90, surgem muitos trabalhos, e quando se olham os trabalhos, em geral, notase que os livros ou são muito técnicos - por exemplo, sobre como se monta a tela, sobre a quantidade de pixels, ou seja, algo em torno da técnica, puramente ou só falam da questão teórica, sem nenhuma ponte com a aplicação prática. Já eu considero importante essa via de mão dupla: fazer, pensar sobre o que se fez; fazer outra vez a partir do que se pensou, pensar outra vez, fazer... Entre 92 e 98, é que começamos a produzir multimídia. De fato, a multimídia surge nessa época. Antes, não existia nem esse termo, porque o computador não tinha som, não se conectava em rede, não tinha nada disso. Essa arte que é feita para ser exibida, vista ou consumida num computador não existia. Tinha-se o computador como ferramenta de auxílio à produção de uma arte que ia ser vista em outro meio: em vídeo, ou no papel, através da editoração eletrônica, da computação gráfica. Mas, na década de 90, temos o impacto do surgimento do CD-Rom, que traz um aumento assustador na capacidade de memória do computador, e vai promover a ideia de que este pode ser uma ferramenta de comunicação. O computador começa nas exatas, como ferramenta de cálculo, depois vira uma ferramenta de trabalho para várias áreas - por exemplo, na literatura, para produzir livros - e depois ele agrega uma outra camada, que consiste em ser também um instrumento de comunicação. Vamos ler no próprio computador aquilo que foi produzido nele. Então, ele se adapta, se prepara para essa nova função, e há, inclusive, um momento em que se tem isso com a internet ainda embrionária. A internet estava a 1.2 Kbps. Para se ter uma ideia, a internet numa linha telefônica analógica era $56 \mathrm{Kbps}$. E hoje nós estamos falando de 3 megas (3.000 Kbps) de velocidade em nosso celular. Simultaneamente, começa a vir uma série de programas. O primeiro programa de hipertexto que eu comprei chamava-se 
Guide, o qual foi extinto, porque veio a multimídia e passou por cima dele. Mas era o primeiro programa em que se podia marcar textos, sublinhá-los e "linkar" outros. Houve também o HiperCard. Na verdade, essa coisa de pensar é isso. Você é jogado nesse meio e precisa pensar: "O que eu estou fazendo?"

Patrícia: No início da entrevista, você tocou, de certa forma, em questões que, lá no início de sua carreira, na década de 80 , e ao longo do século $\mathrm{XX}$, a poesia vinha se colocando, como a crise de verso, por exemplo, e algumas outras questões que são muito relevantes no âmbito da literatura. Como o uso das tecnologias de que você está falando pode atender a esses impasses, a esses problemas que são colocados pela e para a poesia?

Álvaro: No âmbito deste Simpósio [II Simpósio Internacional e VI Simpósio Nacional de Literatura e Informática], tivemos vários momentos em que se discutiu isso. A minha visão é a de que essa tecnologia específica de que estamos falando não tem nada de excepcional em relação a todas as outras. Eu escrevi na pedra, escrevi no papiro, inventei o rolo, fui copista. Veio a imprensa. Veio a publicidade. Mallarmé vê que o tipo pode crescer e diminuir. Lá no século XIX, já se vê o embrião desse tipo de possibilidades. Há sempre uma ligação entre a poesia e a tecnologia da época. Pode-se compor a página de uma forma nova. Quando surge a tecnologia digital, as perguntas que eu faço são: "Que novas perguntas teremos?", "Que novos desafios a poesia vai enfrentar?", "Que descobertas faremos?". Ela traz novas perguntas e, ao mesmo tempo, nos remete a velhas indagações. Isso me fascina, e se trata, no meu caso, de uma visão mais pessoal da literatura. $O$ que me atrai na literatura é que ela é uma espécie de diálogo fora do tempo e do espaço. Eu sempre tive atração por autores taoístas da China, de sei lá quantos anos antes de Cristo, e também por autores americanos do século XIX, como Henry Thoreau. Encanta-me muito quando eu leio e vejo pessoas tão atuais em épocas e lugares tão distantes. Esse diálogo é o que me impacta psicologicamente. Eu quero conversar com essas pessoas, com essas épocas.

Rogério: Isso me faz pensar no Grão, um dos seus últimos trabalhos, feito com o software Managana. Nesse trabalho, há um trânsito da linguagem no qual a palavra prescinde de tradução, ou seja, ela pode ser assimilada em vários 
sistemas linguísticos. Há uma espécie de busca por uma matriz primitiva que acaba por revigorar os arquétipos que são associados a essas culturas e a essas linguagens. Pensando nisso, como você vê a relação dessa obra com a poesia das décadas passadas, da década de 60 , especialmente, em que havia a intenção no sentido de se fazer uma poesia "transmídia"?

Álvaro: Eu acho que tem tudo a ver. Trata-se de uma busca não só minha, mas de muitos autores, e por vários caminhos, o que, para mim, é muito claro pessoalmente. É uma coisa que me atrai. Eu gosto de ler porque gosto de encontrar essas pessoas incríveis, geniais, lúcidas. Eu tenho até aquela ideia do Fernando Pessoa no poema "Sou Lúcido", a qual é mais para um poeta do que para um sonhador. É um sonho lúcido, mas é uma luz. Se se pensa em alguém como Pessoa mesmo ou como outros, questiona-se: "Como uma pessoa em uma condição tecnológica e social tão diferente da nossa é capaz de nos tocar de uma forma tão intensa, tão bem feita?" Quando larguei a medicina para trabalhar com literatura - resolvi trabalhar sobretudo com poesia - eu me dei um curso. Criei um curso pessoal para mim mesmo. Estudei música na Fundação de Música. Comecei a estudar português, porque eu também não estudava gramática, linguística ou literatura. Gosto muito de linguística, de estudar estruturas gramaticais e sintáticas de outras línguas. A história de Grão já começa justamente nessa época. É um texto que tem mais ou menos uns vinte anos que estou escrevendo. Assim, ele é o meu último livro porque é o primeiro.

Patrícia: Em Fogo, outra de suas criações, há um procedimento que retoma a ideia do palimpsesto. Cremos também que se possa pensar num "poemarascunho" (atribui-se a Francis Ponge a ideia do poema "canteiro de obras") ou mesmo numa arqueologia da gênese do poema. Há um poema mais curto e conciso que teria como seu antecedente um poema mais longo e discursivo. $\mathrm{Na}$ sua concepção, qual seria a importância desse tipo de procedimento?

Álvaro: A história desse livro é interessante porque ele é uma reescrita do meu primeiro livro publicado. Logo que resolvi trabalhar com poesia, ainda bem jovem, estudante, eu fiz um livro que se chamava $O$ Beijo que Virou Poesia, com poemas de amor, na linha de outro livro que eu tinha: Nessa Estrada que Leva a Algum Lugar. O Beijo que Virou Poesia é uma obra com esse tipo de temas afeitos a quem está começando a se aproximar da poesia. Na época de publicá-lo, eu o 
apresentei para alguns colegas, amigos que hoje são escritores também, e todos falaram: "Isso aí não é poesia. Desconsidere". A edição pequena, de 500 exemplares feitos pelo próprio autor, "morreu" e nunca mais me ocupei com esse livro. De certa forma, até o tirei da minha lista de "livros oficiais". O livro é de 1984. Mas, em 2002, numa conversa com meu pai, ele assinalou que muitas pessoas gostavam desse livro e que consideravam interessantes aqueles poemas. Ele me sugeriu, então, reescrevê-lo. Nessa época, eu já estava trabalhando muito com essa coisa de fazer livros para o suporte digital. Achei a proposta dele interessante e fiz um experimento. Peguei aqueles mesmos textos e tentei extrair deles a ideia principal. Fiz um exercício de concisão, de enxugamento, ou seja, um exercício formal em cima daquilo, mas mantendo, com essa brincadeira, a ideia de cada poema. Tem-se, ali, o mesmo número de poemas, com a mesma ideia. $\mathrm{Na}$ hora de fazer a versão eletrônica, veio a ideia de deixar para o leitor essa primeira camada textual subjacente ao texto que, agora, eu já considerava poético. Então, passando-se o mouse ou clicando em cima do texto já condensado, tem-se uma revelação daquele primeiro texto, e vice-versa. Pode-se ir e voltar, deixando-se, de certa forma, o rastro da ideia surgindo até ela ter a forma final. Fiquei muito impressionado depois que vi o resultado desse exercício. Isso puxou, para mim, uma discussão sobre forma e conteúdo. Consigo ver que as ideias estavam ali, na primeira versão. Eu queria dizer alguma coisa que, depois, com a segunda versão, consegui dizer com mais precisão. Mas aquilo já estava ali de alguma maneira. Então, esse resultado foi bastante interessante. Eu fiz uma primeira versão impressa do livro e, depois, uma segunda, eletrônica. Nessa versão eletrônica, troquei o primeiro título, porque não gostava dele. Eu o considerava longo. Então, passei de O Beijo que Virou Poesia para Fogo, o qual tem uma relação com o tema do amor. Foi essa a experiência desse livro.

Rogério: Isso me remete, de certa forma, à ideia de uma "escrita infinita". É interessante que, nesse aspecto, o meio digital funciona em uma outra perspectiva para reativar o palimpsesto anterior. Ou seja, o mesmo livro já é outro.

Álvaro: Esse foi o resultado final. Confesso que, em alguns momentos, fiquei tentado a apagar o texto antigo, pois não achava que ele tivesse a qualidade que 
eu gostaria que meus textos tivessem. Mas encontrei resistência de leitores. Várias pessoas - inclusive você, Rogério - me falaram: "Não. Isso aí tem que ficar, pois gera interesse". E uma coisa do eletrônico é que quem quiser ver esse percurso da primeira versão para a segunda, e vice-versa, o encontra lá. Para quem não quiser ver, ele se torna invisível. Pode-se simplesmente ler o texto consolidado e pronto. Trata-se de algo interessante da literatura digital, porque você pode organizar vários percursos, várias camadas de leitura e várias obras diferentes na mesma obra. Eu assumi isso de uma forma para o meu trabalho, que, há dois ou três anos, tenho publicado tudo seguindo algo que já se tornou comum na linguagem do software, que é explicitar para as pessoas a versão: "Estamos agora no Fogo 2.3, 3.0, 4..." Enquanto eu estiver vivo, as coisas vão acontecendo e a obra vai se remodelando.

Rogério: Mas o texto da primeira versão do livro tem a sua qualidade. Às vezes, nos esquecemos de que o nosso conceito sobre o que é bom ou ruim na poesia também depende de uma época. Você não acha?

Álvaro: Eu concordo. Acho que depende da época e de quem lê. Penso que, hoje em dia, na arte eletrônica, todo texto está entre quem está escrevendo e quem está lendo. Ele está fazendo esse trânsito. Mas, no caso específico a que nos referimos, não só esses meus vários colegas, poetas experimentados, não gostaram do livro, como eu mesmo já não estava gostando, baseado na minha formação, a qual, claramente, é influenciada pelo tempo e por outros fatores. Como artista, eu sempre penso que, antes de mais nada, eu tenho uma pessoa difícil a ser convencida de que aquilo presta. Essa pessoa terrível, pela qual eu tenho de passar, sou eu mesmo. Ainda mais hoje, numa era em que há registro de tudo. Devemos registrar o que, de fato, vai fazer diferença. $E$ eu achava que esse trabalho não fazia diferença. Quando o reeditei, sim, achei que fez. Como me satisfiz com a segunda versão, não vejo problema em deixar o que seria 0 "rascunho" ou a primeira apresentação da ideia disponível.

Rogério: Você considerou, há pouco, a questão amorosa nessa obra. O amor é, na verdade, o grande tema de toda a literatura, o amor ou o desamor. Portanto, uma das coisas que nós pensamos é que o "fogo" pode ser uma metáfora do 
amor e pode ser também uma força anímica da natureza, o que certamente pode ser retomado pela ligação do seu trabalho com os elementos das culturas primitivas. Portanto, esses dois sentidos são engendrados pelo seu processo criativo.

Álvaro: Concordo. Inclusive, eu ressalto o fato de o título anterior ser $O$ Beijo que Virou Poesia e depois se tornar Fogo. Eu penso que o "fogo" não somente é uma metáfora de algo como "que seja eterno enquanto dure". O fogo tem uma relação muito forte com o amor, com a paixão. Aliás, trata-se de uma referência bastante comum. Em várias mitologias e estruturas arquetípicas, o "fogo" é aquilo que destrói alguma coisa antiga preparando o espaço para uma coisa nova. Ele é um elemento transformador. Então, eu creio que ele se encaixou na obra com essa dupla aptidão. Eu gosto disso na poesia: uma palavra que pode cintilar vários sentidos. Que pode ser isso ou aquilo. E qual é o sentido? A pessoa que está lendo é que tem de pegá-lo.

Rogério: É a "dupla chama", de Octavio Paz, ou "incerta chama", conforme o poeta e crítico português Manuel Gusmão.

Álvaro: Agora, fazendo uma brincadeira, eu digo que o amor é, sim, um tema muito presente na literatura e, certamente, nos primeiros livros de poesia. O Beijo que Virou Poesia teve apenas 500 exemplares feitos numa gráfica rápida. E houve um livro anterior a ele que eu nem cheguei a publicar. Esse outro texto, que se poderia considerar como o meu primeiro apanhado de poemas, chamava-se Nessa Estrada que Leva a Algum Lugar. Posteriormente, ao longo da minha vida, lendo livros de poetas estreantes, essa ideia de uma estrada, de um caminho, ou de sei lá o quê que vai dar em algum lugar, também é muito recorrente. [Muitos risos]

Patrícia: Eu gostaria que você falasse um pouco sobre o enquadramento de sua poesia na vertente brasileira que envolve, ao mesmo tempo, a poesia impressa, 0 videopoema e o meio digital. Tendo em vista o telurismo que caracteriza esse trabalho com elementos como "fogo" e "grão", arquétipos das culturas primitivas que deram origem aos povos, pode-se dizer que você é um poeta diferente dos outros que fazem esse mesmo tipo de trabalho no Brasil? É possível pensar em 
sua obra como algo que se singulariza a partir de um vínculo com as raízes da literatura mineira?

Álvaro: Eu penso que quem está trabalhando com esse tipo de texto e esse tipo de experimentação são as pessoas que estão se projetando na questão da vanguarda e da herança das vanguardas. Certamente, não são aqueles que estão pesquisando as rimas clássicas ou outros gêneros da poesia tradicional os que estão se atirando no sentido de explorar o limite dessa poesia em relação à imagem, ao som ou à música, jogando-a no meio computacional para ver o que acontece. Isto cria, de certa forma, o que eu chamo de meu grupo de convivência. Para me pensar como autor, a maioria das pessoas com as quais eu convivo são aquelas que estão na praia dos desdobramentos pós-concretistas, no sentido de uma busca pela poesia no que diz respeito a romper com a linguagem e tentar coisas novas. Às vezes, eu me sinto um pouco sozinho - mas, claro que ninguém está completamente sozinho - porque tenho um interesse muito amplo pela literatura e pelo texto. Tem gente que brinca dizendo que isso seria um aspecto do astrônomo ou do geólogo, o que, por sinal, trata-se de coisas que me fascinam. Eu tenho toda uma pesquisa voltada para uma temporalidade dilatada. Aquele mapa que surge no Grão é simplesmente o mapa mundi do universo. É o Sloan Digital Sky Survey: todas as galáxias, clústeres e quasares que a humanidade já viu mapeados. Eu gosto desses deslocamentos que nos jogam muito longe. Eu penso que, de alguma maneira, isso afeta a nossa escrita, porque afeta o nosso processo mental. Nesse sentido, eu tento ser menos datado. Não me sinto fazendo uma crítica à vanguarda. Embora eu esteja no seio dela, tenho muita dificuldade com a ideia do progresso, ou seja, a ideia de que alguma coisa nova está chegando e matando as outras, e que essa agora é que vale e aquelas anteriores ficaram caretas, antigas, bobas ou não servem mais. Porque, à medida que se olha para a frente e para trás, vê-se que o processo mental da humanidade é muito mais feito de idas e vindas, vais e vens, de algo que acontece, desacontece e acontece outra vez. Então, eu tenho esse olhar para várias direções. Em Fogo, há o exercício de concisão. O Librare também tem um super exercício de concisão, porque é só verbos e substantivos, e tem essa mesma lógica de tentar condensar. Há o poema condensado de um lado e o seu 
desenvolvimento de outro. Mas há outro livro, Viagem com o Rio São Francisco, em que os títulos dos poemas são enormes, na linha daqueles livros antigos: "De como eu fui, cheguei e encontrei sei lá o quê". São títulos-parágrafos, que existiam muito e não existem mais. Nesse livro, eu fiz uma viagem no sentido de pesquisar em dicionários antigos sinônimos que já se extinguiram: "surdiu", em vez de "surgiu", por exemplo. Então, na verdade, eu faço uma espécie de trânsito entre tendências diferentes no meu trabalho. Gosto de não me reconhecer entre um livro e outro.

Rogério: O Librare é constituído por poemas-ideogramas.

Álvaro: Sim. Ele surgiu no auge da minha leitura em torno da ideografia. Nele, há poemas com substantivos no singular e verbos no infinitivo de um lado e, de outro, o desenvolvimento desses vocábulos. Inclusive, logo no início da carreira da Maria Esther Maciel, ela conheceu esse livro e me pediu para usá-lo com crianças em aulas de criação artística, na escola. Depois, ela me mostrou o resultado do trabalho e me disse que foi "um barato" dar alguns daqueles textos aos meninos para que eles fizessem algo em cima. Eles fizeram opções válidas e incríveis de poemas, voltando à questão da essência.

Rogério: O dispositivo é um jogo também. A partir dele pode-se soprar, balançar...

Álvaro: Sim. Além disso, o taoísmo é algo bastante naturalista. Ele prega uma simplicidade de vida, um despojamento, uma sabedoria não letrada, ou seja, diz que a vida "legal" é a vida mais natural possível, em uma forma mais simples. Entretanto, no outro livro, Viagem com o Rio São Francisco, eu já trago outro viés. Dou títulos-parágrafos aos poemas, recupero formas arcaicas de dizer. Isso é o que eu acredito que me diferenciaria um pouco em relação às pessoas com as quais eu ando mais. Mas, de toda maneira, por meio da convivência, eu aprendo mais e troco mais com os que estão na fronteira do que com aqueles que estão pensando na escrita de uma forma mais instituída, mais tradicional. Porém, não 
tenho a crença de que estamos melhorando porque veio a vanguarda, a neovanguarda, a "pós" isso ou aquilo.

Rogério: Não se trata de uma melhora. São transformações.

Álvaro: Isso. São transformações.

Patrícia: O software livre Managana, no qual você trabalha juntamente com o designer e programador Lucas Junqueira, permite a criação de comunidades de navegação e de troca de experiência de leitura. Pensando na questão da recepção das obras, você veria nessa possibilidade um viés inovador no que se refere ao papel do leitor de poesia?

Álvaro: A história do software Managana é bastante interessante porque ela é imbricada com a poesia. Trata-se de algo que surge, inclusive, da necessidade que tínhamos de um software para lidar com os fluxos imagéticos, a animação de texto e a conexão de texto com imagem e com som no ambiente multimídia, dentre outras coisas. Algo que marcou muito a minha carreira em antes e depois foi o Sítio de Imaginação, o qual foi uma proposta de fazer uma obra-software, ou seja, um software que fosse uma obra e que fosse publicado. E ele o foi, em 2002, na versão 1.0, já apropriando-se desse conceito dos softwares, e chegando, posteriormente, até a versão 6, na qual estamos agora. Ou seja, a obra já passou por seis grandes transformações estruturais ao longo de seus mais de dez anos. Fomos fazendo a sua estruturação usando o Flash, um software bastante utilizado na multimídia e na animação. Quando chegamos à versão 6, nos propusemos a um desafio. Eu falei ao Lucas Junqueira para fazermos o seguinte: separar o software da obra e transformá-lo em um produto, que vem a ser um software livre para publicação digital. Então, nós tentamos fazer com que esse software funcione em cima de todas essas lógicas e ideias que fomos construindo ao longo do tempo, a partir da publicação das obras poéticas. Portanto, como eu já disse em alguns dos meus ensaios, resolvi abolir a ideia de autor e leitor ou espectador. Ao tratar idealmente a noção de obra digital, eu penso em três categorias: propositor, mantenedor e comunidade. Uma obra digital tem várias versões. Então, ela não acaba na primeira versão. Ela continua 
existindo com as outras versões. Várias pessoas podem entrar, sair, trabalhar, fazer coisas com essa obra. Então, há a discussão sobre quem é autor da obra e quem não o é, como estamos discutindo neste Simpósio. Portanto, proponho pensarmos a partir de outra concepção: a ideia de Imaginação Digital, com a qual procuro descategorizar e, depois, recategorizar os conceitos. Não é para acabar com tudo ou dividir as coisas em mídia e texto. Na verdade, penso em um jeito de agruparmos as coisas de outra maneira. Então, cheguei ao pensamento que segue. Em toda publicação digital, há uma ou mais pessoas que propuseram (por exemplo, alguém pensou em fazer o Liberdade $^{1}$ e chamou outras pessoas para participar da execução do projeto). A essa articulação primeva, eu chamo de proposição. Depois que a obra é proposta, o seu conteúdo se torna disponível e passa a ser frequentado por comunidades. Há vários tipos de comunidades que vão frequentar a mesma obra, pelos mais diversos motivos, e com níveis de leitura também diferentes. E o que chamo de mantenedores seria uma dessas comunidades que, no caso do digital, é extremamente importante. Ela pode ser uma pessoa só ou um grupo que vai cuidar da integridade dos dados, atualizando o programa, o software, o qual é diferente do livro, que não consome energia, por exemplo, para se manter. Eu tenho que pagar à FAPESP para manter o endereço da obra digital, pagar ao provedor para ter um espaço no disco, pagar energia elétrica e atualizar o software. Portanto, o Managana já é todo pensado dessa maneira, conforme a qual eu acredito que as obras digitais podem se articular. $O$ que é chamado de projeto em um programa de editoração eletrônica é o que nós denominamos comunidade, por se tratar de uma publicação em uma comunidade. Ou seja, eu crio uma comunidade e the proponho algo, publicando um conteúdo inicial. A partir daí, esse conteúdo vai evoluindo nos diálogos e nas trocas entre as pessoas que estão frequentando essa comunidade de alguma maneira. Outra coisa que o Managana tem de bastante interessante é que, apesar de eu ser alguém que vem da literatura impressa, penso que não faz sentido ficarmos pensando em página na tela. Essa é uma metáfora que todo mundo já resolveu "bombar" há muito tempo, mas que ainda é, disparadamente, a ideia

\footnotetext{
${ }^{1}$ Referência à obra digital Liberdade, desenvolvida coletivamente pelos criadores participantes do II Simpósio Internacional e VI Simpósio Nacional de Literatura e Informática, realizado pelo Núcleo de Pesquisas em Informática, Literatura e Linguística - Nupill, em Florianópolis, em dezembro de 2013.
} 
predominante, como na noção de página web, dentre outras. A estrutura da apresentação das coisas na tela era sempre paginada, usando-se o impresso como metáfora. Na multimídia, os primeiros programas começaram com a página, depois houve uma coisa ligada ao teatro, como, por exemplo, no Director, no Flash, em que a área onde vão ser colocadas as coisas é chamada de "stage" ("palco"), e em que as mídias são atores. O teatro ofereceu uma grande metáfora à multimídia a partir de um certo tempo, e que foi utilizada por muita gente. Eu mesmo utilizei em um trabalho de vídeo interativo que fiz com o grupo Galpão, a partir de um palco que roda etc. Contudo, essa metáfora teatral também não satisfazia totalmente. Ela parava em certos limites. Quase todo mundo que pensa o digital em termos de interface tem como metáfora ideal - como sonho de consumo - a mente, a nossa cabeça, o "As We May Think" (título de um texto de Vannevar Bush, publicado em 1945, e que é referência no meio), ou seja, como talvez nós pensamos. A partir disso, se vai estruturar toda a navegação, toda a história. O Managana parte dessa ideia. Nele, eu não estou construindo páginas ou telas, mas tenho um ambiente onde haverá uma comunidade que pode compartilhar fluxos de imagens descategorizados. O software mixa, sequencia e gera interação entre playlists. Eu crio no Managana uma playlist descategorizada, mais ou menos assim: "vídeo, vídeo, áudio, texto", por exemplo. A ideia é a de que as coisas estão sempre acontecendo e fluindo. Nada está parado. Quando você quiser, você para. Você vai lá e aperta o "pause". Isso, inclusive, é uma posição maravilhosa que eu descobri depois para o texto, pois ele passa a ser uma possibilidade de se parar o tempo. Se eu paro o tempo, eu mato o vídeo, eu mato a música, mas o texto, não. No Managana, nós retiramos a página do centro da interface. Ele retirou a metáfora da página e passou a usar essa outra metáfora dos fluxos. Assim, ele funciona como se fosse um editor de vídeo ou de áudio. Em um premiére ou em um programa de vídeos ou jogos, não se tem aquela time line ou linha do tempo? No Managana, cada imagem tem a sua própria time line, e o programa tem uma segunda time line na qual todas as outras time lines entram. Através do software e das interações, eu vou posicionando as outras time lines - para frente, para trás, trocando elementos, passando, aumentando, diminuindo. Ou seja, eu vou sequenciando, mixando e gerando interação entre elas. Então, essa é a estrutura básica do Managana em termos 
filosóficos. Nós pegamos tudo isso e o promovemos como software livre. Ele possui o Managana.org e o Managana.art.br, nos quais o software está desconectado da obra. Ali, você pode pegá-lo e escrever o que quiser, criar uma comunidade sobre qualquer tipo de assunto, e pode, inclusive, modificar aquilo de que não gostou. Ele permite tudo isso. E o Managana também tem outra coisa mais prática como seu diferencial: ele é um software para publicação em meio digital. Ele tenta acompanhar a realidade dos multidispositivos, que é a tendência do presente. Tudo está conectado na internet e você passa a sua vida dialogando com telas dos mais variados tipos. Você tem a tela do celular, a tela do tablet, a tela da televisão, que agora também entrou no processo de digitalização. Eu não tenho televisão, mas vejo tudo no NetFlix, dentre outros. Você encontra o produto, escolhe a hora e o modo como você quer ver. O Managana, de certa forma, faz isso. Ele tem uma série de módulos, mas, a grosso modo, posso dizer que ele tem um módulo de edição, que você instala, e ele, como um Wordpress ou outro desses programas de blogue, vai criar as suas comunidades. Aliás, ele tem toda uma série de ferramentas para a gestão dessas comunidades: licença de edição, licença de leitura para determinar, dentre os participantes, quem pode escrever e quem pode ler. Trata-se de algo que determina quem pode escrever o quê, e quem pode ler 0 quê. Há também a licença de interação, pois existem camadas de interação diferenciadas, em função dos diferentes tipos de pessoas que participam das comunidades.

Rogério: A questão dos direitos autorais é também inerente a essa liberação do software. Como você lida com essa questão, tendo em vista que todas as suas obras, em suas várias versões, estão disponibilizadas na internet, além de outros trabalhos seus que não se restringem necessariamente à poesia?

Álvaro: Hoje, a maior parte das obras de que participo, está publicada sob duas licenças. A parte de software está publicada sob a licença da Free Software Foundation, que é a LGPL, um modelo do software livre. Já os conteúdos sobre os quais posso ter autoria, conforme a legislação vigente, eu publico com uma licença da Creative Commons Brasil 3.0. Olha, que interessante: a licença também tem suas versões. A LGPL está na versão 3, e parece que acabou de sair uma nova. A Creative Commons 3 flexibiliza o direito autoral vigente 
explicitando que a cópia e a manipulação do material para o uso pessoal e para o que se chama "fair use", como na educação, são autorizadas, desde que quem está usando cite e credite a fonte. O uso comercial continua restrito a uma autorização expressa. Quanto ao software, pode-se fazer uma utilização comercial do meu material, desde que a publicação comercial seja publicada sob o software livre. Isso foi o resultado de uma longa pesquisa nossa procurando tentar navegar nessa situação que ainda está longe de ser resolvida. Pelo contrário, ela se torna cada vez mais problemática. Muita gente confunde software livre com software grátis. Mas a própria Free Software Foundation deixa bem claro que uma coisa não tem a ver com a outra. Na verdade, você pode e deve cobrar pelos seus trabalhos publicados no software livre. As pessoas devem pagar por eles, se puderem. Mas o que software livre faz, que é muito interessante, na minha opinião - inclusive, a Creative Commons também tem esse modelo, de certa forma - é pregar a ideia de que quando construo alguma coisa, no campo da arte ou em outro qualquer, estou produzindo em cima de alguma coisa que já me foi dada pela cultura, pela sociedade ou por outras pessoas que já fizeram algo parecido antes. Eu entro ali, dou as minhas pinceladas, faço a minha modificação nesse caldo e devolvo. Então, seria absurdo eu não deixar que os outros fizessem o mesmo sobre o meu trabalho. Essas licenças todas são muito duras quanto à questão da apropriação. Elas evitam que alguém se aproprie da obra alheia. E esse é um problema. Para dar um exemplo bem conhecido na área de software, todos esses sistemas operacionais atuais, como o Windows (a partir do Windows NT), o software da Apple e mesmo o software padrão livre do Linux, derivam do Unix, um sistema operacional desenvolvido na universidade, sem nenhuma preocupação com dinheiro ou remuneração. O que vemos é que as grandes organizações pegaram esse modelo, se apropiaram desse conhecimento - elas não começaram do zero - fizeram modificações e, um belo dia, falaram: "Agora, isso aqui é meu e ninguém mais pode usar. Se alguém quiser usar, tem que me pagar”. A lógica do software livre é a de que se pode usá-lo, mas não se pode tomá-lo. Isso passa pela ideia de liberdade. Eu sou livre para interferir nas coisas que me são dadas de uma forma gentil, generosa, mas não para roubá-las. No entanto, se pensarmos filosoficamente sobre a questão do direito autoral, eu creio que ela 
imbrica uma série de conceitos que, na minha opinião, são bastante diferentes. Para mencionar alguns problemas que ainda não estão resolvidos nessa área, posso apontar o fato de que, como eu já disse, estou nesse ponto em que, dentro da legislação vigente, dentro do que existe em termos legais, é onde eu posso estar. Entretanto, a própria estrutura do digital destrói os contornos de autoria. Então, como vamos resolver essa questão em obras nas quais a autoria se coloca de uma forma bem mais complexa do que em outras situações? Como vamos, por exemplo, tentar dividir o peso de autores que participaram em momentos diferentes ou cujo trabalho teve durações diferentes no processo de criação? Além disso, essas obras também incluem uma autoria por parte do leitor ou do espectador. Então, como se resolve isso também? A ideia de autor entra em choque com isso que eu tenho sugerido por enquanto: a ideia do propositor, das comunidades de edição e de fruição e um tipo de comunidade que eu chamo de mantenedores, que são aqueles que vão manter a integridade da obra, pois, diferentemente do suporte de papel ou mesmo fotográfico, nos quais se atinge uma permanência muito maior no tempo, o suporte digital envolve consumo de energia elétrica, servidores e softwares que vão se alterando muito rápido. Portanto, obras que não recebem manutenção são condenadas a desaparecer rapidamente.

Rogério: O Managana, de certa maneira, propõe essa ideia, essas comunidades.

Álvaro: Exatamente. O Managana vem de uma experiência de seis versões de um software que viemos desenvolvendo no Sítio de Imaginação, para pensar novas formas de publicação de poesia e de poiésis. Eu hoje utilizo esta palavra porque ela tem a ver com "fazer", ou seja, mantém a questão da poesia, mas expande o conceito para outros meios que não o texto. Assim, eu esclareço que não se trata do termo poesia stricto sensu. O programa é feito pensando-se nos vários círculos e camadas, tanto de fruição ou leitura quanto de produção de conteúdo. Esse tipo de ambiente permite essa imbricação. Em meus textos ensaísticos mais recentes, eu penso muito nessa ideia de descategorizar e recategorizar. Parece-me que o foco já não é mais pensar sobre quem é autor da obra e quem não o é. Certamente, isso já mudou. Será que não conseguiremos 
encontrar outras categorias que consigam delimitar, mesmo que imprecisamente, essa discussão, ou seja, de uma forma nova ou que seja mais adequada?

Rogério: No seu entender, esse trabalho que você faz nas redes, essa consciência que você tem acerca das comunidades colaborativas de criação tem alguma ligação com o aspecto da agitação cultural da qual você participou através da edição de periódicos e de leituras no espaço público, na perspectiva de ampliar o público da poesia?

Álvaro: Essa pergunta é interessante, porque, se eu lembrar da minha trajetória pensando nessa perspectiva, desde o início, sempre estive envolvido com pessoas e grupos de atividades que estavam buscando ampliar o acesso à poesia e expandir as condições e locais de leitura. Por exemplo: na época da Oficina Literária, fizemos poesia em rádio, na rádio Alvorada. Fizemos também um projeto chamado Vale Poesia, que foi o primeiro projeto feito em Minas nesse sentido. Depois, a prefeitura chegou a se apropriar dessa ideia, que consistia em poemas-cartazes para pregar nos ônibus. Na década de 80 , fizemos um acordo com a Metrobel, a administradora das empresas de ônibus da capital mineira à época. Durante uma semana, nós espalhamos nos ônibus esse material, o qual veio a ser o que hoje se chama Jornal do Ônibus. Mas, na época, era poesia. Além disso, editamos muitos livros de autores de poesia. Também estamos editando, ultimamente, poesia em pen drive, na internet, em pdf, etc.

Rogério: O processo coletivo com a coleção Orbital, o Dezfaces...

Álvaro: Eu participei também da Poesia Orbital e do Dezfaces, onde circulou um volume colossal de poetas. Inclusive, como já falei, eu entro no digital para facilitar o meu trabalho braçal, o meu trabalho não criativo, como autor. Então, descubro que se tratava de algo que também nos permitia ampliar as fronteiras da circulação da nossa poesia e começo a correr atrás disso. Eu sempre brinco que, quando surgem novas tecnologias, elas vêm para resolver um problema que existia. Depois que elas existem, a gente descobre diversas outras coisas com as quais sequer se sonhava. Por exemplo: o processador de textos era para substituir a máquina de escrever, mas depois descubro que ele vai servir para 
uma série de outras coisas, pois, com ele, a gente começa a animar a poesia e, com isso, esta começa a ter temporalidade. Mas, sem dúvida, sempre me interesso pela ampliação do público da poesia. A gente, realmente, se sente muito sozinho. Diante do volume de coisas que são publicadas em relação à população como um todo, a dispersão poética ainda é muito pequena. Portanto, temos de lançar mão de todo tipo de ferramenta possível.

Rogério: Há pouco, você mencionou a publicação de livros em pen drive. Ao acessarmos o site Ciclope.art, verificamos que ali há uma loja em que você publica o conteúdo de livros ou de vídeos através de pequenas caixas que nos devolvem o espaço do mundo analógico e material. Como você tem experienciado esse trabalho?

Álvaro: Poderíamos terminar esta conversa falando sobre isso. Foi interessante a palestra do Rui Torres [via teleconferência, no II Simpósio Internacional e VI Simpósio Nacional de Literatura e Informática] para mim. Uma das coisas de que ele falou que me chamou mais a atenção foi quando ele começou a mapear os momentos da relação entre $o$ texto e a tecnologia no século XX. Num primeiro momento, a poesia vai largar o papel e entrar na tela, vai expandir as suas possibilidades de interação com o áudio e com o visual. E, depois, se informatizar. Foi nessa época que comecei, e me cansei de "levar pedrada". Apenas para citar alguns exemplos do que eu ouvia sobre poesia e computadores: "Isso é coisa de matemática", "Para isso, é preciso fazer cálculo", "Como se pode colocar poesia numa máquina tão fria?" Agora, vivemos num outro momento, no qual explodiram a internet e as redes sociais, em que ninguém mais duvida que vídeo, áudio, música, literatura e tudo o mais possam existir no meio digital, na grande rede. Então, eu tenho percebido, nas novas gerações, a situação contrária. Esse pessoal que tem sido chamado de Geração $Y$, que nasceu a partir do final dos anos 90 e início dos 2000 e que, desde os dois anos de idade, já brinca com tablet, com telefone, com internet etc., padece de algo inverso. É o processo do Yin e Yang. Ou seja, é uma geração que está muito conectada, muito online, e tem pouquíssimo contato com coisas concretas, no sentido de objetos, de coisas físicas. Portanto, se eu fosse mais ousado, falaria assim: "Chega! Eu quero continuar sendo de vanguarda e agora eu vou ser analógico. Nada de digital. $\mathrm{O}$ 
futuro será analógico" [Risos]. Claro que estou brincando. De toda maneira, como vivo antenado nessas coisas, eu pensei em fazer um sistema em que pudéssemos ter todos esses mundos dialogando entre si, mais uma vez em cima da proposta de ampliar o público do nosso trabalho e expandir a dispersão da poesia. Criamos uma loja no site na qual ofertamos o que eu chamo de "conteúdos conexos aos conteúdos online". Nós criamos um modelo de negócio duplo, no qual todo conteúdo publicado online possui a licença Creative Commons. Então, eu vou vender publicidades, assinaturas etc. e vou dividir as eventuais receitas entre os autores desses conteúdos, na proporção dos acessos a eles. Esse é um modelo que estamos copiando do NetFlix e da biblioteca online da Vivo, por exemplo. Creio que esse modelo vai se espalhar "como uma praga" no meio digital. Ele funciona da seguinte forma: você tem bibliotecas ou acervos grandes e as pessoas pagam um valor por mês para usar esse material do jeito que quiserem. Eu já tive oportunidade de ver esse tipo de contrato, e ele funciona dessa maneira: o editor pega aquela quantidade de dinheiro, separa um percentual para a operação do sistema, e tem também um percentual para os autores, que é dividido em função dos acessos. A própria leitura gera a remuneração proporcional para cada título.

Rogério: É mais justo, não?

Álvaro: Sim. É um sistema que eu considero mais justo. A ideia é que o conteúdo online funcione como uma vitrine ou mostruário dos produtos conexos que estão à venda na loja. Assim, eu não violo a minha a regra, que é a de não proibir o acesso às minhas obras em função do dinheiro. Em contrapartida, se a pessoa quiser pagar, para ter um objeto "bacana", eu posso mandar para ela. Também publicamos esses mesmos conteúdos para uso local, em pen drive, novamente com a licença Creative Commons. Os outros estão online, mas o usuário depende da conexão, depende de mantermos os dados da obra no servidor, dentre outras coisas. Eu penso que o pen drive, além de ter a beleza da coisa materializada - é um pedaço físico de memória que você manda para alguém - também envolve uma discussão que está muito em voga nesta era da vigilância e da hiperconexão: a ideia de que temos de fomentar e estimular as redes não 
centralizadas, de que temos de fazer a informação circular com certo "descontrole". Essa é uma questão até mesmo relacionada à sobrevivência da espécie humana. O que os grandes estão fazendo é ter tudo online. O notebook do Google, por exemplo, não permite ao usuário ter arquivos locais. Isso é um design deliberado. Como assim? E quando eu estiver sem conexão? Não vou conseguir trabalhar. E se explodir uma bomba lá no Google e destruir o database deles? Eu perco toda a minha história, toda a minha memória, toda a minha vida.

Rogério: A Apple também está usando esse modelo.

Álvaro: A Apple também. Esse é o modelo dos grandes. Então, é interessante brincar com a ideia de criar circulações colaterais. E não vamos parar por aí. Como falei, a ideia da loja é oferecer conteúdos locais conexos. Então, vamos fazer os conteúdos circularem em forma de pen drive. Já temos também a opção de as pessoas adquirirem coisas em DVD, e em papel também, em livros, objetos, cartazes. Enfim, em outros tipos de mídia que possamos inscrever.

Rogério: Álvaro, obrigado pela entrevista, a primeira para a nossa série "Conversas com Criadores Digitais Brasileiros", que certamente muito contribuirá para os leitores da Texto Digital.

Texto recebido em: 07/07/2014. 